\title{
Tourmaline compositions and textures: reflections of the fluid phase
}

\author{
Barbara L. DUTROW*, Darrell J. HENRY \\ Department of Geology \& Geophysics, Louisiana State University, Baton Rouge, LA, 70803, USA; Dutrow@lsu.edu \\ * Corresponding author
}

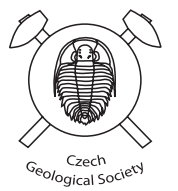

Tourmaline uniquely records evidence of its geologic history in its composition and, if properly decoded, provides insight into the geologic environment of formation. Recent studies suggest that tourmaline not only retains chemical information on the host-rock environment, but also provides signatures on the fluid phase with which it interacted. Such signatures are embedded in its major- and minor-element compositions as well as in its isotopes. Some of these elemental signatures are qualitative, while others provide quantitative evaluation of the evolving fluid-phase compositions. Chemical fingerprints of interacting fluids are found as compositional variations in each of the tourmaline structural sites. Boron, a fluid-mobile element, can be used to monitor local release of boron from the breakdown of pre-existing B-bearing minerals or it can provide evidence for infiltration of external fluids. The exchange of $\mathrm{Fe}^{3+}$ for $\mathrm{Al}$ in deprotonated tourmalines along the oxy-dravite to povondraite join $(\mathrm{O}-\mathrm{P}$ trend) is generally consistent with tourmaline formation coexisting with fluids in an oxidizing, saline environment. Fluorine can serve as a marker for F-bearing aqueous fluids, but the crystallochemical constraints associated with vacancies on the $\mathrm{X}$ site and the resulting increase in local charge on the Y site must be considered. In some cases, quantitative information derived from $\mathrm{Na}, \mathrm{Ca}$, $\mathrm{K}$, and vacancies allow calculation of the compositions of select components in the co-existing fluids. While isotopes provide valuable insights into fluid-related processes, their signatures are beyond the scope considered here.

Insights into geological processes in fluid-rich environments can be inferred by the presence of tourmaline as well as by tourmaline compositions. For example, tourmaline forming along shear zones suggests that enhanced permeability accompanied infiltration of $\mathrm{Na}$ and B-bearing fluids. Oscillatory-zoned tourmaline from geothermal systems captures chemical, thermal, and mechanical feedback from non-linear fluid behavior at critical conditions in the $\mathrm{H}_{2} \mathrm{O}$-system. In other cases, textural, morphological and chemical changes in tourmaline mark the transition from magmatic-to-hydrothermal conditions during the evolution of igneous systems. Consequently, signatures in tourmaline can be indicators of the fluid-phase composition and, in some cases, provide quantitative estimates of ion concentrations in the fluid in addition to its host rock environment. Capturing these chemical signals of fluids preserved in tourmaline extends its petrogenetic utility.

Keywords: tourmaline, fluid composition, hydrothermal, salinity, non-linear behavior, ore deposits Received: 18 November, 2017; accepted: 16 May, 2018; handling editor: J. Cempirek

\section{Introduction}

Insights into the conditions responsible for formation of various geological terrains can be interpreted from textures and chemical variations in minerals. Some minerals are better suited for this role than others, and tourmaline is one of the best. Tourmaline supergroup minerals, accessory phases in most rocks, have the ability to adjust their compositions to record geologic information on conditions under which they formed and their limited volume diffusion preserves these signatures throughout the rock cycle (e.g. Henry and Dutrow 1996; van Hinsberg et al. 2011a, b). For example, studies demonstrate that tourmaline compositions reflect the composition of the host $\operatorname{rock}(\mathrm{s})$ in which they crystallize (e.g. Henry and Guidotti 1985; Henry and Dutrow 1996). Consequently, tourmaline has been used widely to determine the provenance of its original source rock(s) (e.g. Henry and Dutrow 1992; Morton et al. 2005). In addition, it is well established that the isotopic signatures in tourmaline (e.g. B, H(D), O, Li, Sr, Si and Mg) reflect the source, fluid interactions, fluid transport, and temperatures during the evolution of the tourmaline and many more isotopic systems may be explored (e.g. Marschall and Jiang 2011; Trumbull et al. 2011). More recently, studies indicate that selected major and minor chemical components in tourmaline represent signatures of the fluid phase with which tourmaline interacted (e.g. Dutrow et al. 1999; von Goerne et al. 2001, 2011; Henry et al. 2004; van Hinsberg 2011; Henry and Dutrow 2012; Berryman et al. 2016; van Hinsberg et al. 2017).

Evidence of tourmaline's sensitivity to the fluid phase is observed in a range of textural features. These textures include, for example: dissolution-reprecipitation features where tourmaline dissolves leaving scalloped and irregular boundaries overgrown by new tourmaline of a different composition (e.g. Dutrow and Henry 2000; Henry et al. 2004), distinct overgrowths on pre-existing 
tourmaline such as detrital cores, intricate and complex chemical zoning patterns (e.g. Norton and Dutrow 2001; Lussier and Hawthorne 2011; Pezzotta and Laurs 2011), the growth of large tourmaline single crystals (e.g. Cook 2013), the development of late-stage tourmaline fibers (e.g. Dutrow and Henry 2000, 2016) and more subtle fluid-mineral interactions such as tourmaline pseudomorphing or replacing another phase (e.g. Dutrow et al. 1999; Etzel et al. 2015).

Fluids interacting with tourmaline can be sourced internally or externally; both typically leaving their signature. In most cases, fluids sourced internally from the host rock are in equilibrium with the coexisting mineral assemblage (a "rock-buffered" system). Alternatively, fluids sourced externally, outside of the tourmaline's local domain, may be out-of-equilibrium with the tourmalinebearing mineral assemblage (a "fluid-buffered" system) and drive fluid-rock interactions. Consequently, tourmaline can also be used to discriminate between closed- and open-system conditions in its growth environment. Thus, the formation and growth of tourmaline can track fluid availability, transport and infiltration and, in turn, tourmaline chemistry can be used to deduce compositional information on the character of the interacting fluids formerly present in the rock system (e.g. Dutrow and Henry 2016).

Isotopes, particularly B isotopes, are well suited to distinguish between fluid sources; those internally derived from the host rock or externally derived (e.g. Marschall et al. 2009). Boron isotope zoning and exotic B-isotopic values are sensitive to small amounts of fluid infiltration and may signal fluid influx (e.g. Marschall et al. 2009). However, consideration of isotopic signals is beyond the scope of the current paper and readers are referred to excellent reviews by, for example, Marschall and Jiang (2011), Trumbull et al. (2011), and Marschall and Foster (2018).

Tourmaline occurrence in low-to-high pressure-temperature $(\mathrm{P}-\mathrm{T})$ geothermal, hydrothermal and metamorphic systems is primarily as an accessory phase. As such, tourmaline passively responds to fluid compositions because it occurs typically in too low abundance to exert significant control on the composition of the fluid phase. Recently, estimated partitioning coefficients allow quantitative estimates to be made for a range of cations interacting with tourmaline in a subduction-zone environment (van Hinsberg et al. 2017). These theoretical data are complemented by experimental data (e.g. von Goerne et al. 2011). Thus, tourmaline chemistry provides both qualitative and quantitative signatures of its fluid environment. This contribution reviews selected chemical signatures encapsulated in tourmaline during its growth that are reflective of the interacting, coexisting fluids and their compositions.

\section{Tourmaline components and fluids}

\subsection{Tourmaline crystallographic background}

To understand the manner in which these fluid-related chemical constituents are incorporated into tourmaline, selected background in its crystallographic structure is useful. The tourmaline-supergroup minerals are characterized by the general structural formula of $\mathrm{XY}_{3} \mathrm{Z}_{6}\left(\mathrm{~T}_{6} \mathrm{O}_{18}\right)$ $\left(\mathrm{BO}_{3}\right)_{3} \mathrm{~V}_{3} \mathrm{~W}$ (e.g. Henry et al. 2011). The most common constituents of each site for the purposes of this paper are: ${ }^{[9]} \mathrm{X}=\mathrm{Na}^{1+}, \mathrm{Ca}^{2+}, \mathrm{K}^{1+}, \square$ (vacancy); ${ }^{[6]} \mathrm{Y}^{1+} \mathrm{Fe}^{2+}, \mathrm{Mg}^{2+}$, $\mathrm{Al}^{3+}, \mathrm{Li}^{1+} ;{ }^{[6]} \mathrm{Z}=\mathrm{Al}^{3+}, \mathrm{Fe}^{3+}, \mathrm{Mg}^{2+} ;{ }^{[4]} \mathrm{T}=\mathrm{Si}^{4+}, \mathrm{Al}^{3+} ;{ }^{[3]} \mathrm{B}$ $=\mathrm{B}^{3+} ; \mathrm{V}=\mathrm{OH}^{-}$and $\mathrm{O}^{2-}$; and $\mathrm{W}=\mathrm{OH}^{-}, \mathrm{F}^{-}$and $\mathrm{O}^{2-}$ (see Hawthorne and Henry 1999; Henry et al. 2011 for additional details). Although there are 33 approved tourmaline species, only a few are important here (Tab. 1). Compositions and formulae discussed follow the site assignment procedures of Henry et al. (2011).

\subsection{Boron, trigonal site}

An essential element required for the formation of tourmaline is boron (B). Consequently, nucleation and growth of tourmaline tracks the availability of boron in the system, whether from rock, fluid, melt and/or vapor. Boron has a distinctive role in each of these environments. Relative to co-existing melt, B partitions into the vapor phase (e.g. Dingwell et al. 1996). Boron is a fluid-mobile element, easily redistributed in an aqueous fluid (e.g. Leeman and Sisson 1996). To reach conditions in aqueous fluids most favorable for tourmaline growth, neutral-to-acidic conditions are required such that $\mathrm{B}$ is predominantly in triangular coordination in the fluid, the same coordination as most boron in tourmaline (e.g. Morgan and London 1989; Henry and Dutrow 1996; Leeman and Sisson 1996). In contrast, B is primarily tetrahedrally coordinated in alkaline fluids and tourmaline becomes destabilized or fails to nucleate (e.g. van Hinsberg and Schumacher 2011). Based on estimated thermodynamic data, as $\mathrm{B}(\mathrm{OH})_{3}$ activities increase in the fluid phase, the stability of tourmaline increases, provided that other constituents are present at sufficient activities (e.g. $\mathrm{Na}, \mathrm{Fe}, \mathrm{Al}, \mathrm{Si}$; von Goerne et al. 1999; see Dutrow et al. 1999; Kister et al. 2005 for activity-activity diagrams). Typically, for B-bearing fluids that are internally derived, B is released to the rock system from the breakdown of B-bearing minerals with increasing temperature. For example, at low grades of metamorphism, B is likely released from the breakdown of clay minerals, and at higher temperatures from micas (e.g. Henry and Dutrow 1996, 2012). Initially, the tourmaline primarily develops as distinct overgrowths commonly on pre-existing detrital cores of a different composition (e.g. Henry and Dutrow 1992). Individual discrete chemical 
Tab. 1 Tourmaline species useful for determining fluid signatures

\begin{tabular}{|c|c|c|c|c|c|c|c|}
\hline Species & $(\mathrm{X})$ & $\left(\mathrm{Y}_{3}\right)$ & $\left(\mathrm{Z}_{6}\right)$ & $\mathrm{T}_{6} \mathrm{O}_{18}$ & $\left(\mathrm{BO}_{3}\right)_{3}$ & $(\mathrm{~V})_{3}$ & (W) \\
\hline \multicolumn{8}{|l|}{ Alkali group } \\
\hline Schorl & $\mathrm{Na}$ & $\mathrm{Fe}_{3}^{2+}$ & $\mathrm{Al}_{6}$ & $\mathrm{Si}_{6} \mathrm{O}_{18}$ & $\left(\mathrm{BO}_{3}\right)_{3}$ & $(\mathrm{OH})_{3}$ & $(\mathrm{OH})$ \\
\hline Fluor-schorl & $\mathrm{Na}$ & $\mathrm{Fe}_{3}^{2+}$ & $\mathrm{Al}_{6}$ & $\mathrm{Si}_{6} \mathrm{O}_{18}$ & $\left(\mathrm{BO}_{3}\right)_{3}$ & $(\mathrm{OH})_{3}$ & (F) \\
\hline Oxy-schorl & $\mathrm{Na}$ & $\mathrm{Fe}^{2+}{ }_{2} \mathrm{Al}$ & $\mathrm{Al}_{6}$ & $\mathrm{Si}_{6} \mathrm{O}_{18}$ & $\left(\mathrm{BO}_{3}\right)_{3}$ & $(\mathrm{OH})_{3}$ & (O) \\
\hline Dravite & $\mathrm{Na}$ & $\mathrm{Mg}_{3}$ & $\mathrm{Al}_{6}$ & $\mathrm{Si}_{6} \mathrm{O}_{18}$ & $\left(\mathrm{BO}_{3}\right)_{3}$ & $(\mathrm{OH})_{3}$ & $(\mathrm{OH})$ \\
\hline Fluor-dravite & $\mathrm{Na}$ & $\mathrm{Mg}_{3}$ & $\mathrm{Al}_{6}$ & $\mathrm{Si}_{6} \mathrm{O}_{18}$ & $\left(\mathrm{BO}_{3}\right)_{3}$ & $(\mathrm{OH})_{3}$ & (F) \\
\hline Oxy-dravite & $\mathrm{Na}$ & $\mathrm{Al}_{2} \mathrm{Mg}$ & $\mathrm{Al}_{5} \mathrm{Mg}$ & $\mathrm{Si}_{6} \mathrm{O}_{18}$ & $\left(\mathrm{BO}_{3}\right)_{3}$ & $(\mathrm{OH})_{3}$ & (O) \\
\hline Elbaite & $\mathrm{Na}$ & $\mathrm{Li}_{1.5} \mathrm{Al}_{1.5}$ & $\mathrm{Al}_{6}$ & $\mathrm{Si}_{6} \mathrm{O}_{18}$ & $\left(\mathrm{BO}_{3}\right)_{3}$ & $(\mathrm{OH})_{3}$ & $(\mathrm{OH})$ \\
\hline Fluor-elbaite & $\mathrm{Na}$ & $\mathrm{Li}_{1.5} \mathrm{Al}_{1.5}$ & $\mathrm{Al}_{6}$ & $\mathrm{Si}_{6} \mathrm{O}_{18}$ & $\left(\mathrm{BO}_{3}\right)_{3}$ & $(\mathrm{OH})_{3}$ & (F) \\
\hline Povondraite & $\mathrm{Na}$ & $\mathrm{Fe}_{3}^{3+}$ & $\mathrm{Fe}^{3+}{ }_{4} \mathrm{Mg}_{2}$ & $\mathrm{Si}_{6} \mathrm{O}_{18}$ & $\left(\mathrm{BO}_{3}\right)_{3}$ & $(\mathrm{OH})_{3}$ & (O) \\
\hline Bosiite & $\mathrm{Na}$ & $\mathrm{Fe}_{3}^{3+}$ & $\mathrm{Al}_{4} \mathrm{Mg}_{2}$ & $\mathrm{Si}_{6} \mathrm{O}_{18}$ & $\left(\mathrm{BO}_{3}\right)_{3}$ & $(\mathrm{OH})_{3}$ & $(\mathrm{O})$ \\
\hline \multicolumn{8}{|l|}{ Calcic group } \\
\hline Feruvite & $\mathrm{Ca}$ & $\mathrm{Fe}_{3}^{2+}$ & $\mathrm{Al}_{5} \mathrm{Mg}$ & $\mathrm{Si}_{6} \mathrm{O}_{18}$ & $\left(\mathrm{BO}_{3}\right)_{3}$ & $(\mathrm{OH})_{3}$ & $(\mathrm{OH})$ \\
\hline Liddicoatite & $\mathrm{Ca}$ & $\mathrm{Li}_{2} \mathrm{Al}$ & $\mathrm{Al}_{6}$ & $\mathrm{Si}_{6} \mathrm{O}_{18}$ & $\left(\mathrm{BO}_{3}\right)_{3}$ & $(\mathrm{OH})_{3}$ & $(\mathrm{OH})$ \\
\hline Fluor-liddicoatite & $\mathrm{Ca}$ & $\mathrm{Li}_{2} \mathrm{Al}$ & $\mathrm{Al}_{6}$ & $\mathrm{Si}_{6} \mathrm{O}_{18}$ & $\left(\mathrm{BO}_{3}\right)_{3}$ & $(\mathrm{OH})_{3}$ & $(\mathrm{~F})$ \\
\hline \multicolumn{8}{|l|}{$\mathrm{X}$-site vacant group } \\
\hline Foitite & $\square *$ & $\mathrm{Fe}_{2}^{2+} \mathrm{Al}$ & $\mathrm{Al}_{6}$ & $\mathrm{Si}_{6} \mathrm{O}_{18}$ & $\left(\mathrm{BO}_{3}\right)_{3}$ & $(\mathrm{OH})_{3}$ & $(\mathrm{OH})$ \\
\hline Oxy-foitite & $\square$ & $\mathrm{Fe}^{2+} \mathrm{Al}_{2}$ & $\mathrm{Al}_{6}$ & $\mathrm{Si}_{6} \mathrm{O}_{18}$ & $\left(\mathrm{BO}_{3}\right)_{3}$ & $(\mathrm{OH})_{3}$ & (O) \\
\hline Magnesio-foitite & $\square$ & $\mathrm{Mg}_{2} \mathrm{Al}$ & $\mathrm{Al}_{6}$ & $\mathrm{Si}_{6} \mathrm{O}_{18}$ & $\left(\mathrm{BO}_{3}\right)_{3}$ & $(\mathrm{OH})_{3}$ & $(\mathrm{OH})$ \\
\hline Rossmanite & $\square$ & $\mathrm{Li} \mathrm{Al}_{2}$ & $\mathrm{Al}_{6}^{\circ}$ & $\mathrm{Si}_{6} \mathrm{O}_{18}$ & $\left(\mathrm{BO}_{3}\right)_{3}$ & $(\mathrm{OH})_{3}$ & $(\mathrm{OH})$ \\
\hline
\end{tabular}

* X-site vacancy $(\square)$

zones of tourmaline typically reflect this episodic availability of B to the system as minerals destabilize and metamorphic reactions release the $\mathrm{B}$ adsorbed or hosted within the structure of the minerals. However, boron availability decreases with increasing metamorphic grade as micas progressively react, resulting in volumetrically smaller growth horizons as tourmaline continues to crystallize. Trace elements and isotopes reflect this fractionation as a function of temperature. At conditions below the staurolite zone, a larger volume of growth occurs on the $+c$ pole relative to the $-c$ pole, and these polar overgrowths have compositions that are distinctly different (e.g. Dietrich 1985; Henry and Dutrow 1996; van Hinsberg and Schumacher 2007). Such compositional differences facilitate quantification of temperatures and partitioning behavior of tourmaline (e.g. van Hinsberg and Schumacher 2007). Near $700^{\circ} \mathrm{C}$ at low to medium pressures, tourmalines can be thermally destabilized to release B back into the rock system (e.g. Kawakami 2001), although this temperature varies as a function of composition and pressure (e.g. van Hinsberg et al. 2011a).

In melts, $\mathrm{B}$ is incompatible and thus with crystallization continues to increase in concentration in the residual melt until it reaches sufficient values for tourmaline to nucleate and grow if other constituents needed to form tourmaline are available (e.g. London et al. 1996; Pesquera et al. 2013). In granitic melts, the $B$ value required to nucleate tourmaline may be as low as $\sim 500-900 \mu \mathrm{g} \mathrm{g}^{-1}$ (e.g. Pesquera et al. 2013). In some remarkable pegmatites, sufficient boron is present to grow single zoned tourmaline crystals up to $2 \mathrm{~m}$ in length (Cook 2013).
Tourmaline growth due to infiltration of a fluid external to the system is relatively common over a range of geologic conditions. Such an influx typically results in an increase in modal amounts of tourmaline. In lowtemperature hydrothermal systems, fluids with relatively high concentrations of B may develop fibrous tourmaline that nucleates and grows on pre-existing minerals (e.g. Moore et al. 2004; Henry and Dutrow 2012; Dutrow and Henry 2016). For example, the geothermal system at Darajat, Indonesia, had two distinct stages of tourmaline growth in fluid-dominated environments where the influxes of B-bearing fluids formed tourmaline (Etzel et al. 2015; Etzel 2016). Here, the first stage tourmalines are interpreted as a replacement of original igneous minerals such as plagioclase and clinopyroxene due to infiltration of $\mathrm{NaCl}$ and B-bearing aqueous fluids. The next stage of tourmaline growth developed as discrete tourmaline crystals within secondary mineral assemblages (anhydrite) with the influx of descending reactive fluids (Etzel et al. 2015; Etzel 2016). Tourmalines associated with economically valuable mineral deposits are commonly attributed to external fluid infiltration (e.g. Slack 1996; Slack and Trumbull 2011). In some cases, extensive B-rich fluid influx is accompanied by large increases in the tourmaline mode. Hydrothermal tourmalinites, rocks with greater than 15 vol. \% tourmaline, are suggested to be the culmination of massive boron metasomatism (e.g. Slack 1996 and references therein; Baksheev et al. 2011).

Influx of externally derived, B-bearing fluids within a metamorphic system may result in subtle textural and chemical evidence in the tourmaline for infiltra- 
tion. In one such case, the extent of B-fluid infiltration is marked by occurrence of tourmaline concentrated in muscovite-rich pseudomorphs after staurolite (Dutrow et al. 1999). These tourmalines contrast to those formed from internal fluids in that they are chemically homogeneous, contain sillimanite and staurolite inclusions, lack distinct compositional overgrowths, are restricted to the pseudomorph, and absent in the matrix (likely due to dissolution because the original tourmaline composition was out-of-equilibrium). The close spatial relationship of the tourmaline-rich pseudomorphs in the host rocks to the intrusive contact suggests that they represent an advective isograd by marking the extent of B-bearing fluid infiltration into the host rocks from the pluton (Dutrow et al. 1999). In addition, 2D heat and mass transport modeling for this system suggests time scales of fluid flow and indicates that the maximum temperatures required fluid advection and pseudomorph formation to occur in less than 450,000 yrs (Dutrow unpublished data).

In some geologic settings, tourmaline growth likely represents both sources for B-bearing fluids; those internally and externally derived. In all cases, the development and growth of tourmaline preserves signatures of the B-bearing fluid event.

\subsection{The $O-P$ trend; $Y$ and $Z$ sites}

Tourmalines that form in association with aqueous fluids that are oxidizing and/or have low water activities develop a distinctive compositional trend. Deprotonated tourmaline compositions that range from oxy-dravite to povondraite (O-P trend; Tab. 1), described by the $\mathrm{FeAl}_{-1}$ exchange vector (e.g. review in Henry and Dutrow 2012), are commonly associated with modern and ancient highly saline environments. The substitution of $\mathrm{Fe}^{3+}$ for $\mathrm{Al}$ is implied by the inverse relations of these cations and is consistent with oxidizing conditions for tourmaline formation. Tourmalines of the O-P trend (Fig. 1) are found, for example, in xenolithic igneous blocks in metamorphosed caprocks of salt domes (povondraite type locality; Žáček et al. 1998, 2000), active salt domes (Henry et al. 1999), active geothermal systems (e.g. Cavarretta and Puxeddu 1990; Etzel et al. 2015) and $\mathrm{Cu}-\mathrm{Mo}-\mathrm{Au}$ and orogenic gold deposits (e.g. Lynch and Ortega 1997; Hazarika et al. 2015).

In these varied environments with $\mathrm{O}-\mathrm{P}$ trend tourmalines, saline-rich fluids can result from both internal and external sources. Caprocks of salt domes typically contain both halite and anhydrite/gypsum and exhibit evidence for interaction with aqueous fluids. These fluid-mineral interactions generally result in dissolution of halite producing higher salinity aqueous fluids. In geothermal systems, boiling of aqueous fluids is suggested to concentrate $\mathrm{B}(\mathrm{OH})_{3}$ and lead to higher salinity fluids (e.g. Lynch and Ortega 1997). In addition, shallow levels in geothermal systems tend to become more oxidizing which enhances the oxidation of $\mathrm{Fe}^{2+}$ to $\mathrm{Fe}^{3+}$ (Norton 1978). Thus, this feature may promote the replacement of $\mathrm{Al}$ by $\mathrm{Fe}^{3+}$. For example, saline fluids are associated with the Larderello geothermal system, where they are considered effective mineralizing fluids (e.g. Cavarretta and Puxeddu 1990; Lynch and Ortega 1997). Such saline fluids are also interpreted to be present in select ore deposits with O-P tourmaline (e.g. Slack 1996; Baksheev et al. 2011; Hazarika et al. 2015). For example, Hazarika et al. (2015) showed that tourmalines most directly related to gold mineralization in the Hiri-Budini locality, India, contain tourmalines that exhibit the O-P trend, but that tourmalines from nearby gold deposits not directly associated with gold mineralization lack this trend. Typically chlorides enhance the solubility and transport of $\mathrm{Fe}$ and other metals, consistent with the occurrence of ore deposits in systems with enhanced salinity (e.g. Helgeson 1992). The net result of increasing salinity is to decrease the activity of $\mathrm{H}_{2} \mathrm{O}\left(a \mathrm{H}_{2} \mathrm{O}\right)$ and this enables enhanced deprotonation on the $\mathrm{W}$ site of tourmaline to produce oxy-tourmalines (Aranovich and Newton 1996; Henry and Dutrow 2012). Occurrences for most of the reported O-P trend tourmalines appear to be at lower temperatures, ranging from c. 150 to $400{ }^{\circ} \mathrm{C}$ (Henry et al. 2008).

The occurrence of tourmalines along the O-P trend is consistent with high salinity, oxidizing fluids and may be an indicator of such fluids in the geologic past (Fig. 1). Because O-P trend tourmalines have been found in association with ore deposits (e.g. $\mathrm{Au}, \mathrm{Cu}, \mathrm{Mo}$ ), their occurrence may also provide a useful prospecting guide to these types of ore deposits.

\subsection{Anions in the $W$ site}

Fluorine (F) is an aqueous fluid-mobile element and its incorporation into tourmaline is related to interaction with F-bearing aqueous fluids or melts. Fluorine enrichment in a melt phase results in increasing amounts of $F$ in tourmaline such that tourmaline compositions track the overall fractionation trends in igneous rocks such as pegmatites (e.g. Henry and Dutrow 2012; Dutrow and Henry 2016). However, the incorporation of $F$ into the tourmaline structure has crystallochemical limits and is dependent on the X-site charge and local Y-site charge. These constraints make the correlation with fluids less straightforward (Henry and Dutrow 2011). A compilation of over $8800 \mathrm{~F}$-bearing tourmaline analyses demonstrates that when $\mathrm{X}$-site vacancies are $>0.6 \mathrm{pfu}$, a maximum amount of about $0.1 \mathrm{~F}$ pfu is possible in the $\mathrm{W}$ site (see their Fig. 2). Consequently, fluor-tourmaline species are present in alkali and calcic group tourmalines, those with $>0.5$ cations in the X-site, but fluor-tourmaline species are absent in vacancy-dominated tourmaline group (see 

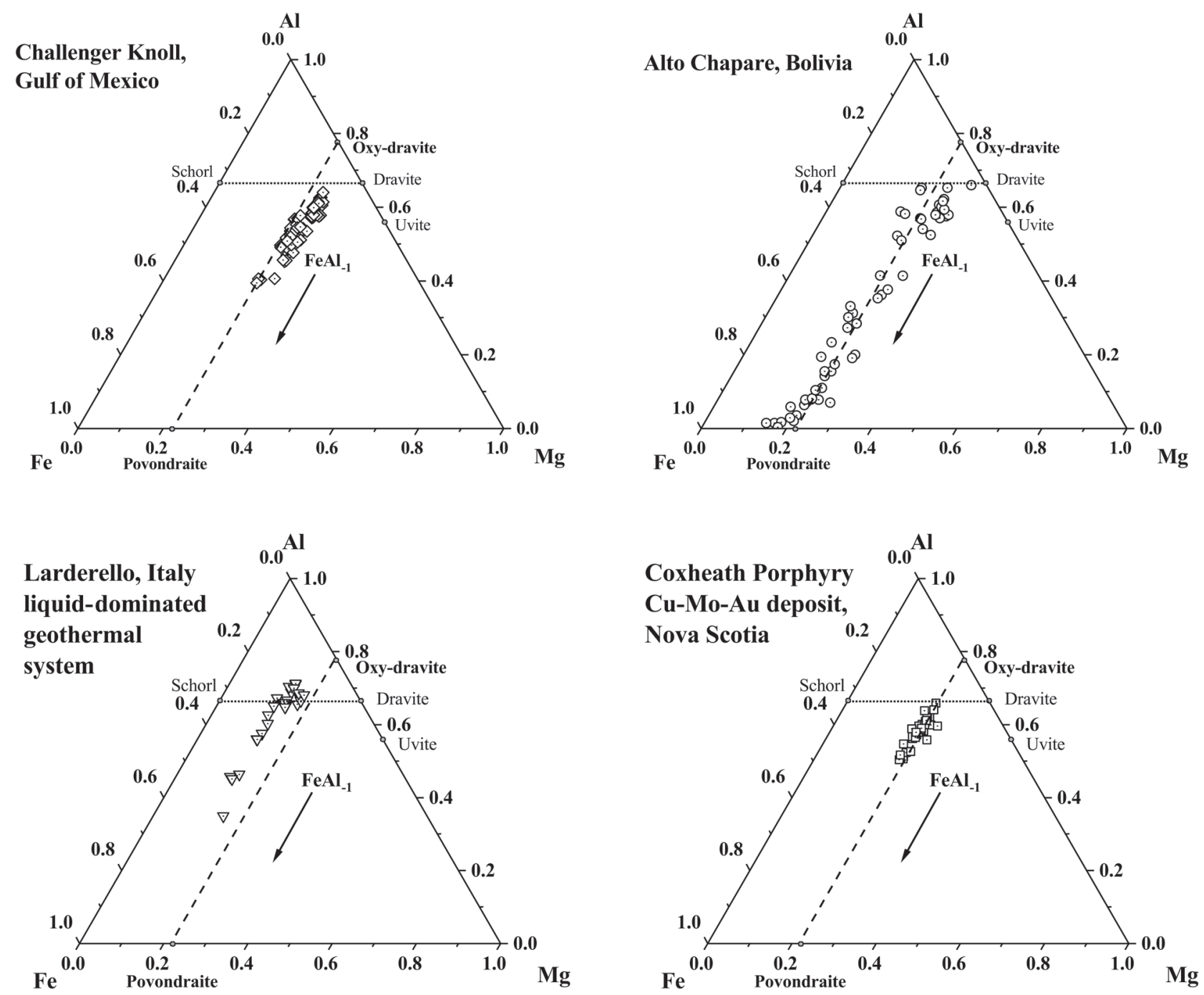

Fig. 1 Tourmalines with compositions from oxy-dravite to povondraite, the $\mathrm{O}-\mathrm{P}$ trend, occur in modern and ancient high-salinity environments suggesting that these compositions may be reflective of saline fluid compositions in the geologic past. Gulf of Mexico tourmalines occur in the caprocks of an active salt dome (Henry et al. 1999); Bolivian tourmalines occur in xenoliths within a salt dome (Žáček et al. 1998, 2000); Lardarello tourmalines are associated with saline fluids in an active geothermal field (Cavarretta and Puxeddu 1990) and Nova Scotia tourmalines are associated with an economic $\mathrm{Au}-\mathrm{Cu}-\mathrm{Mo}$ ore deposit (Lynch and Ortega 1997).

also Henry et al. 2011). This F- $\square$ anti-correlation holds regardless of rock type and for tourmaline co-existing with an F-saturating phase such as fluorite.

For tourmalines with low X-site vacancy, F contents likely track those of the fluid phase. Using thermodynamic data for coexisting minerals and aqueous complexes in a high-P metamorphic terrane, dravitic tourmaline that contains between 0.10 and $0.57 \mathrm{~F}$ pfu is estimated to have crystallized in coexisting aqueous fluids with 2-1400 $\mu \mathrm{g} / \mathrm{g} \mathrm{F}_{\text {fl }}$ (van Hinsberg et al. 2017). Thus, F in tourmaline provides a relative $\mathrm{F}$ indicator and, in some cases, a quantitative measure of $F$ in the fluid coexisting with alkali- or calcic-tourmaline.

As eluded to previously, the amount of $\mathrm{O}^{2-}$ in the $\mathrm{W}$ site has been linked to fluid environments with higher salinity (the O-P trend in tourmaline), a trend consistent with experimental findings. Data from fluid-tourmaline partitioning experiments imply that compositional trends in tourmaline coexisting with lower-to-moderate salinities exhibit substitutions primarily consistent with the $\square \mathrm{Al}(\mathrm{NaMg})_{-1}$ exchange vector. However, with high-Na, more saline fluids, tourmaline follows compositional trends most consistent with the operation of the $\mathrm{AlO}(\mathrm{Mg}(\mathrm{OH}))_{-1}$ deprotonation vector (von Goerne et al. 2001, 2011; Henry and Dutrow 2012). An additional mechanism for increasing the amounts of $\mathrm{O}^{2-}$ on the $\mathrm{W}$ site is through oxidation of $\mathrm{Fe}^{2+}$ as expressed by the $\mathrm{Fe}^{3+} \mathrm{O}\left(\mathrm{Fe}^{2+}(\mathrm{OH})\right)_{-1}$ exchange vector such that this mechanism becomes operative when the coexisting fluid is more oxidizing. 
While chlorine $(\mathrm{Cl})$ can occur in tourmaline, it is currently not considered a good indicator of salinity because it is typically below detection or found in trace quantities in natural tourmaline using standard electron microprobe analytical techniques (Henry and Dutrow 1996). An exception is the recent study by Bačík et al. (2015) where they found tourmaline with up to $0.13 \mathrm{Cl}$ pfu in a hydrothermally altered dioritic porphyry gold deposit from central Slovakia. In general, the significantly larger anionic size of $\mathrm{Cl}^{-}$relative to the other $\mathrm{W}$-site anions makes its incorporation in significant amounts less likely.

\subsection{The X-site; quantitative estimates of fluid compositions}

Recent experimental and theoretical studies of tourmaline-aqueous fluid element partitioning permit quantitative estimates of select fluid phase components to be calculated based on the coexisting tourmaline composition (e.g. von Goerne and Franz 2000; von Goerne et al. 2001, 2011; Berryman et al. 2015, 2016; van Hinsberg et al. 2017). By analyzing $\mathrm{Na}$ and/or $\mathrm{Ca}$ concentrations in aqueous $\mathrm{NaCl}$-bearing fluid coexisting with tourmaline in two assemblages, mathematical relationships were developed that allow calculation of cation concentrations in the fluid phase based on the X-site composition (Na, $\mathrm{Ca}$ and/or X-site vacancy) of the crystallized tourmaline. These data focused on systems with temperatures of $500-700{ }^{\circ} \mathrm{C}$ at $0.2 \mathrm{GPa}$ containing a quartz + chlorite + Al-phase (with albite absent) or quartz + albite + chlorite assemblage and for $\mathrm{Na}$ tourmalines or $\mathrm{Na}-\mathrm{Ca}$ tourmalines. Refitting and extrapolating the partitioning data of von Goerne et al. $(2001,2011)$ by Dutrow and Henry (2016) provides expressions relating the $\mathrm{Na}$ and $\mathrm{Ca}$ in the $\mathrm{X}$-site of tourmaline to $\mathrm{Na}$ and $\mathrm{Ca}$ contents in aqueous fluids assumed to be in local equilibrium with tourmaline + albite + quartz for lower-temperature conditions near $300^{\circ} \mathrm{C}$ and $0.2 \mathrm{GPa}$. Overall, these studies demonstrated that Na-tourmalines form in Na-rich fluids, Ca-rich tourmalines tend to form in Ca-rich fluids, and that the X-site vacancies are largely a function of net ionic strength such that decreasing ionic strength is correlated with X-site vacancies. Data also permit quantification of fluid compositions for these selected components (von Goerne et al. 2011; Berryman et al. 2016).

Similarly, recent experimental studies of $\mathrm{K}$ and $\mathrm{Na}$ incorporation into dravitic tourmaline coexisting with a $\mathrm{KCl}$-bearing fluid suggest that $\mathrm{K}$ progressively increases in the X-site of tourmaline with the concomitant increase of pressure, temperature and $\mathrm{KCl}$ concentration in a Na-absent fluid (Berryman et al. 2015). Using the data of Berryman et al. (2015), an expression relating $\mathrm{K} / \mathrm{Na}$ contents in the aqueous fluids to $\mathrm{X}$-site compositions of Mg-rich tourmaline is derived: $(\mathrm{K} / \mathrm{Na})_{\mathrm{fl}}=\sim 50 \times(\mathrm{K} / \mathrm{Na})_{\text {tur }}$
(Dutrow and Henry 2016). For most crustal conditions, K occurs in trace amounts in Mg-bearing tourmaline. Such small quantities still allow estimation of maximum values for $(\mathrm{K} / \mathrm{Na})_{\mathrm{fl}}$ and $(\mathrm{K} / \mathrm{Ca})_{\mathrm{fl}}$ for a given P-T. If typical Narich tourmaline does contain $\mathrm{K}$, it would form in fluids with high $\mathrm{K}$ contents as suggested by the partitioning data. However, with significant $\mathrm{Fe}^{3+}$ incorporation, the $\mathrm{X}$-site enlarges and can accommodate greater amounts of $\mathrm{K}$ at lower pressures (e.g. Grice and Ercit 1993; Henry and Dutrow 2012). Experimental data for these compositions, however, are currently lacking.

Examples of quantitative calculations of fluid-phase chemistry based on X-site composition are shown for fibrous tourmalines from geothermal environments. In this environment, the absolute $\mathrm{Na}$ concentrations in the coexisting fluid range from 0.11 to $0.47 \mathrm{~mol} / 1 \mathrm{Na}_{\mathrm{fl}}$ with similar $\mathrm{Na}_{\mathrm{ff}}$ concentrations observed for fibrous tourmaline in pegmatitic systems (Dutrow and Henry 2016). It is also demonstrated that fluid concentrations likely exhibit a control on the species of tourmaline that crystallizes: a foititic tourmaline if $\mathrm{Na}_{\mathrm{ff}}<\sim 0.25 \mathrm{~mol} / \mathrm{l}$, and an alkali species tourmaline (schorl or elbaite) if $\mathrm{Na}_{\mathrm{fl}}>$ $\sim 0.35 \mathrm{~mol} / \mathrm{l}$. Assuming an $\mathrm{NaCl}$ equivalent these fluids translate to $14,612 . \mathrm{mg} / \mathrm{l}$ and $20,460 \mathrm{mg} / \mathrm{l}$ TDS (total dissolved solids), less than current seawater salinity of $\sim 35,000 \mathrm{mg} / 1 \mathrm{TDS}$.

Coexisting fluid compositions for a number of components have been reconstructed quantitatively from tourmaline in the Tauern Window subduction-zone environment (van Hinsberg et al. 2017). Here, fluids coexisting with a zoned dravitic tourmaline are described as dilute acidic aqueous solutions with $\mathrm{Na}_{\mathrm{fl}}<0.75 \mathrm{~mol} / \mathrm{l}$. Using a theoretical approach to develop tourmaline/fluid partitioning data for a variety of cations and combining these data with trace-element analyses of tourmaline, the high-pressure coexisting aqueous fluids contain total trace element concentrations of less than $500 \mu \mathrm{g} / \mathrm{g}$ (van Hinsberg et al. 2017). In another study, Berryman et al. (2017) suggested that $\mathrm{Ca} /(\mathrm{Ca}+\mathrm{Na})$ ratios in the fluid ranged from 0.05 to 0.18 during progressive stages of tourmaline growth in the Tauern Window.

\subsection{Additional estimates of fluid compositions}

The theoretical approach used by van Hinsberg et al. (2017) allows quantitative estimates of 21 fluid components in equilibrium with tourmaline to be calculated from tourmaline-fluid partitioning data (e.g. Li, Ba). These data include elements such as $\mathrm{Cr}$ and $\mathrm{V}$, for which no experimental data exist currently. Using his approach, fluid compositions in equilibrium with unusual $\mathrm{Cr}-\mathrm{V}$ bearing tourmaline can be evaluated to provide insight into conditions necessary for their formation. With the wide variety of elements they examined, partition coef- 


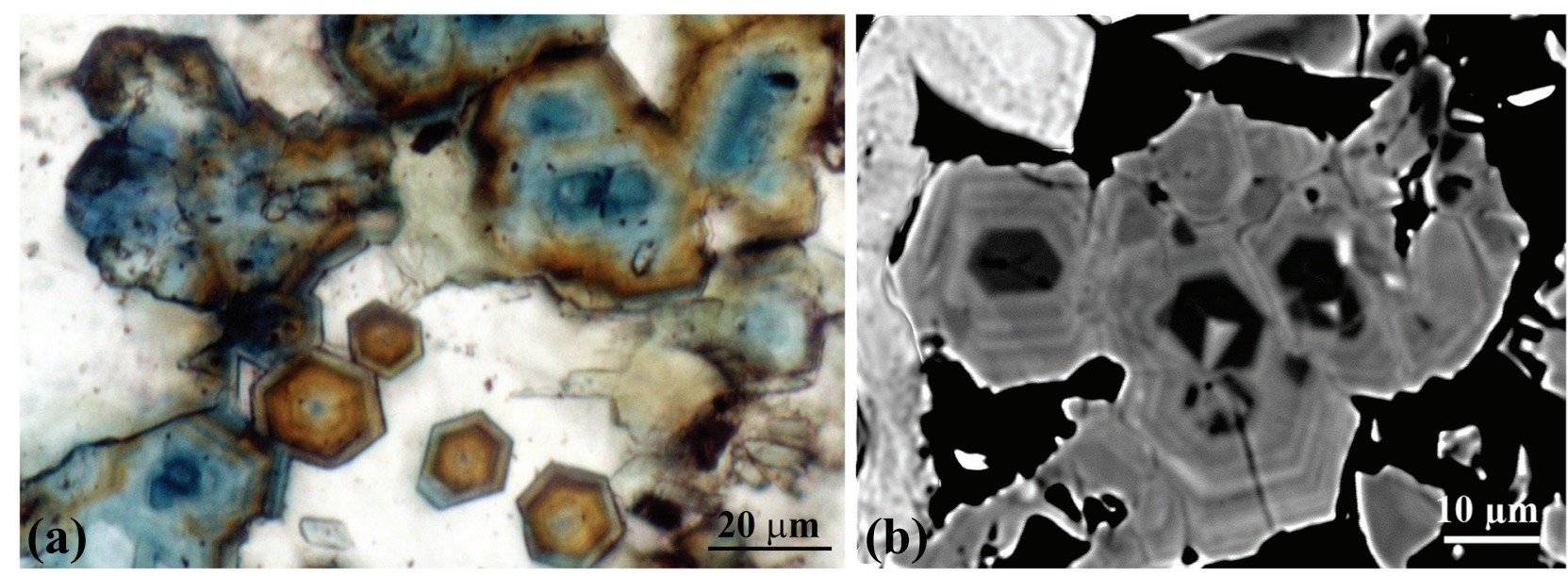

Fig. 2 Small oscillatory-zoned tourmalines from the Geysers Geothermal Field, CA, USA, are interpreted to represent crystallization in dynamically evolving fluids near the critical endpoint in the $\mathrm{H}_{2} \mathrm{O}$ system (see Norton and Dutrow 2001 for details). At these conditions, slight changes in thermal properties lead to large changes in ion activities resulting in fine-scale zoning. a - Plane-polarized light optical image showing the chemically zoned crystals with schorlitic cores and foititic rims. b-Back-scattered electron image displaying the fine-scale oscillations.

ficients between tourmaline and fluid range over five orders of magnitude. Such quantitative estimates of fluid compositions are a promising future avenue of endeavor in tourmaline studies as our understanding of tourmaline chemistry and its embedded fluid signatures expand.

\section{Examples of tourmaline compositions as indicators of fluid composition}

Tourmaline is a mineral of extremes; single crystals range in size from micrometers to meters and compositions span across a broad chemical spectrum from containing largely major rock-forming elements to unusual trace elements such as Sn, V and Cr (e.g. Griffin et al. 1996). Fibrous tourmalines are particularly responsive to changing conditions in fluid-rich hydrothermal environments. A single fiber can be chemically zoned, reflecting multiple periods of dissolution and reprecipitation, such that the fiber's chemical changes track the chemical changes in the host environment and mirror the overall fractionation trend in a pegmatite (e.g. Dutrow and Henry 2000, 2016). All tourmaline varieties, from small to large, embed fingerprints of their fluid environment and record processes of formation as displayed by the following examples.

\subsection{Fluid fluctuations and non-linear behavior in geothermal systems recorded by tourmaline}

In the Geysers, CA, USA, geothermal system, small 20-micrometer oscillatory-zoned tourmalines occur in veins within the felsic carapace (Fig. 2; Norton and Dutrow 2001). Thermal and chemical modelling suggest that the carapace experienced conditions near the critical endpoint in the $\mathrm{H}_{2} \mathrm{O}$ system and at about 80,000 yrs, the system began temperature oscillations with a temporal frequency of about $100 \mathrm{yr}$. Such thermal fluctuations result in dramatic changes in the fluid properties and ion activities (e.g. $\mathrm{B}(\mathrm{OH})_{3}$ ) in the critical region. Growth of the oscillatory-zoned tourmaline is interpreted to record these rapidly changing fluid compositions, due to both thermal fluctuations and thermally induced fracture events that allowed surges of advective flow (Fig. 2). Chemical zones within the tourmaline vary from a core of schorl $\left(\mathrm{X}_{\mathrm{Mg}}=0.78, \mathrm{Na}=0.56 \mathrm{apfu}\right)$ to a foitite rim (X-site vacancy $=0.5, \mathrm{Na}=0.44, \mathrm{Ca}=0.6 \mathrm{apfu})$, but oscillate, as observed by marked color changes in plane-polarized light (Fig. 2; see Norton and Dutrow 2001 for details). Based on these average tourmaline data, calculations suggest that $\mathrm{Na}_{\mathrm{fl}}$ varied at a minimum from 0.30 to 0.37 $\mathrm{mol} / \mathrm{l}$ for a temperature of $370^{\circ} \mathrm{C}$.

Another oscillatory and sector-zoned tourmaline has been reported from a different locality within the Geysers field, suggesting that zoned tourmaline may be a widespread phenomenon (see fig 9 of Jones et al. 2016). The average compositions for this tourmaline are schorlitic-to-foititic (Jones et al. 2016), similar to the compositions found by Norton and Dutrow (2001). Although high spatial resolution chemical data are missing, oscillatory zones are apparent in published images (Jones et al. 2016). In the Geysers system, the oscillatory-zoned tourmalines likely track the consequences of competing chemical, thermal and mechanical transport processes that impacted fluid evolution and provide evidence, on this small scale, of the non-linear systematics in hydrothermal systems. Such feedback in system behavior may explain oscillatory zoning in hydrothermal environments near the critical endpoint of the $\mathrm{H}_{2} \mathrm{O}$ system as thermal perturbations change ion activities and failure events 
(a)

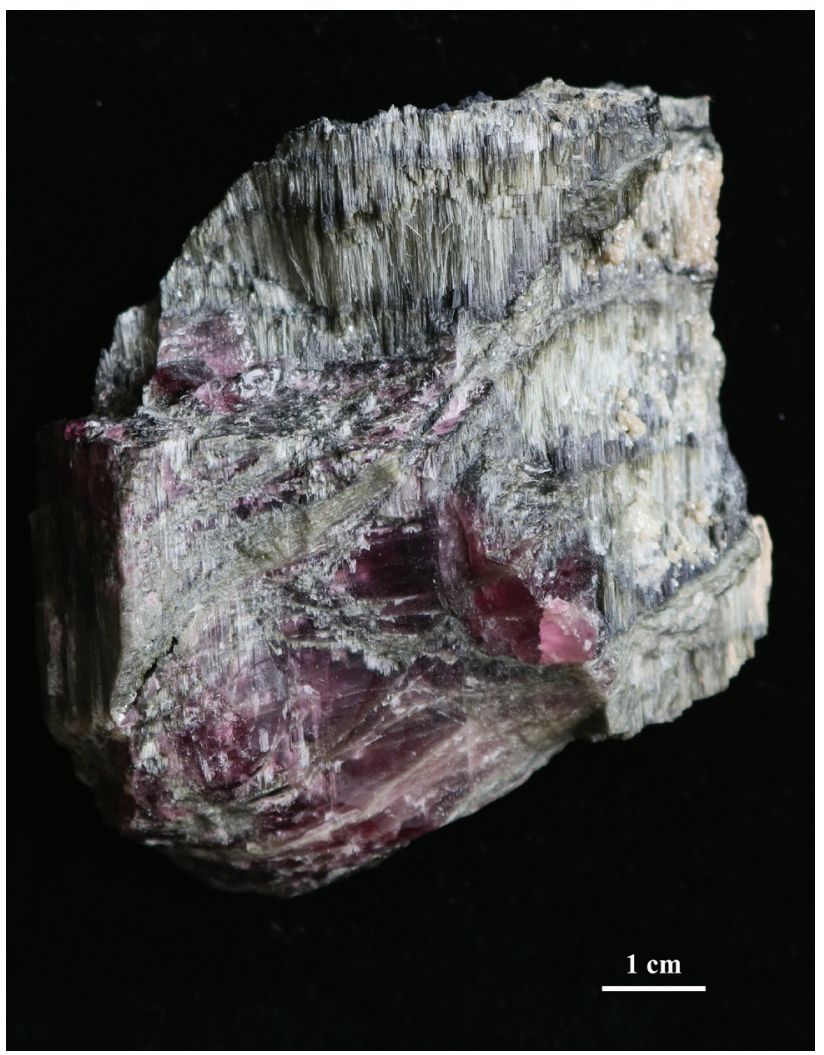

(b)

\section{Cruzeiro fibrous tourmaline}

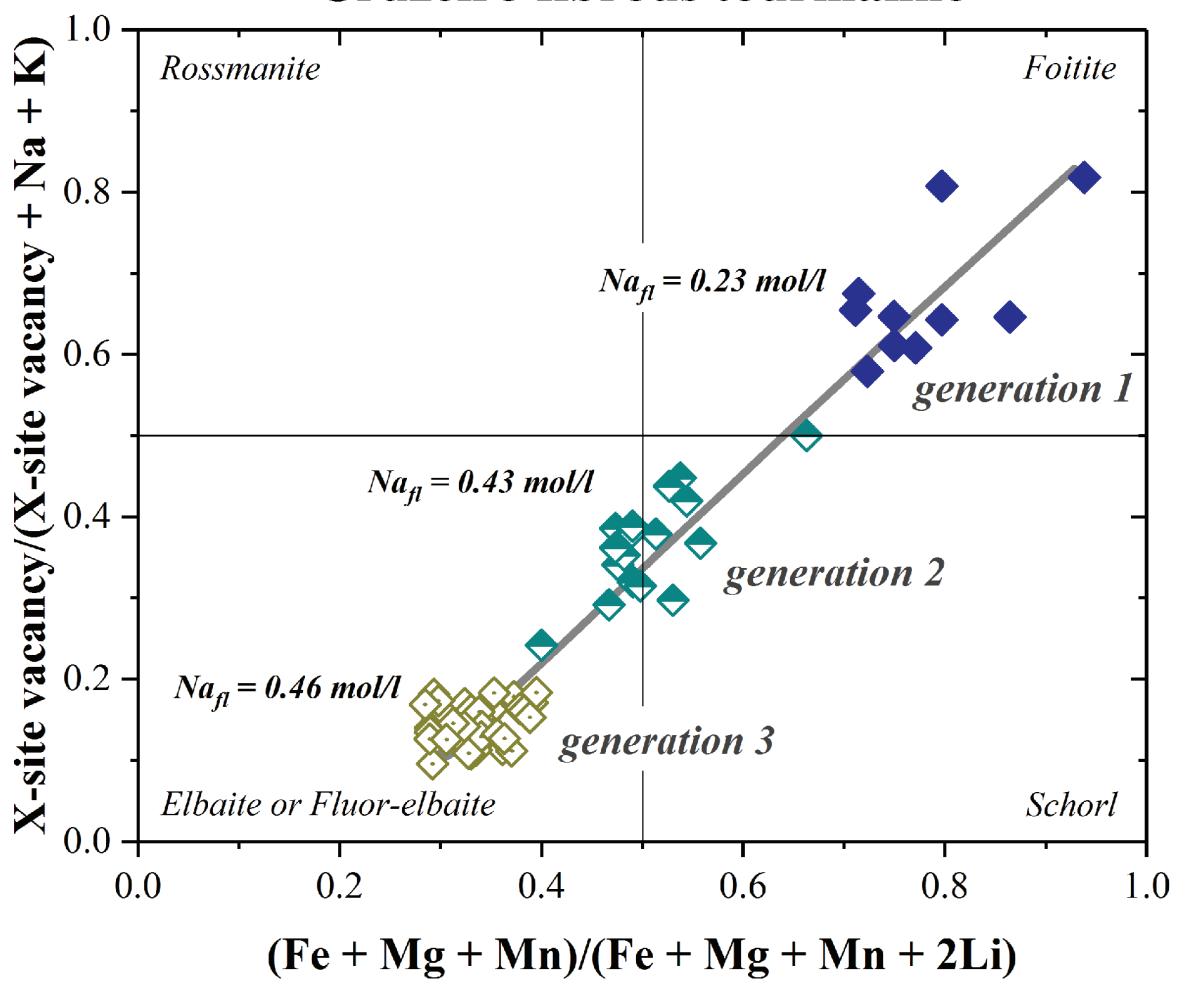

allow influx of compositionally distinct fluids. In other cases, oscillatory zoning may be generated in a fluid with constant composition through the depletion and enrichment of chemical species near the growth surface due to limited diffusion (Marschall pers. comm.). Even small tourmaline can be a sensitive and high-resolution recorder of fluid compositions that track the complex dynamic fluid behavior in the system in which it crystallized.

\subsection{Tourmaline recording the transition from magmatic-to- -hydrothermal environments}

Chemical compositions and changes in tourmaline textures may provide evidence for changes in the processes related to the crystallization history, and with proper decoding can elucidate the chemical evolution of the system (e.g. van Hinsberg et al. 2011a). Tourmaline crystallizes in igneous melts with sufficient B, Si, Al, Fe, Mg, Li and $\mathrm{Na}$, but more commonly

Fig. 3 Tourmaline sample displaying two distinct textures, fibers cutting massive elbaite (Cruzeiro Mine, Brazil) that may reflect the transition from magmatic-to-hydrothermal fluids. a - The original massive pink elbaite, formed during melt crystallization, is cross cut and replaced by grey fibrous tourmaline that crystallized during the hydrothermal stage. b - Diagram displaying the distinct mineral and fluid compositions of the three generations of tourmaline found in each fiber. Fibers are complexly zoned suggesting dramatically changing fluid environments as illustrated by the three generations of tourmaline that partially replace each earlier tourmaline generation. The tourmaline chemical variability, in part, reflects the distinct fluid compositions as shown with associated $\mathrm{Na}_{\mathrm{fl}}(\mathrm{mol} / \mathrm{l})$ for each tourmaline generation (see Dutrow and Henry 2000, 2016 for details). 
it is found in later fluid-filled miarolitic cavities as the required incompatible elements increase in amount with fractionation (e.g. London et al. 1996). Although transitions from magmatic-to-hydrothermal crystallization are indistinct, tourmalines form throughout this crystallization interval and may record the nature of the transition (e.g. Duchoslav et al. 2017).

In the Erongo granitic complex, Namibia, tourmalines are found within granitic rocks as well as in the late-stage miarolitic cavities (e.g. Trumbull et al. 2008; Boudreaux 2014; Lensing-Burgdorf et al. 2017). Tourmalines here have distinct morphologies and textures; some large single crystals are overgrown by needles on the $+c$ pole. In one example, this textural change correlates with compositional variations, from schorlitic compositions in the larger single crystal to foititic compositions of the fibers (fig. 4 of Lensing-Burgdorf et al. 2017). Such a change may mark the magmatic-to-hydrothermal transition during crystallization while the zoning within each textural type likely reflects fluid infiltration and reequilibration events during each pegmatitic phase or pocket rupture.

Another case of tourmaline recording both magmatic and hydrothermal processes is found in a sample from the Cruzeiro Mine, Brazil. Here, zoned grey-green fibers fill crosscutting fractures and replace the original massive dark-pink host (Fig. 3a). Chemical analyses demonstrate that the host is a ${ }^{\mathrm{x}} \square-{ }^{\mathrm{W}} \mathrm{O}-{ }^{\mathrm{W}} \mathrm{F}$-rich elbaite with the average composition: $\left(\mathrm{Na}_{0.54} \square_{0.41} \mathrm{Ca}_{0.05}\right)\left(\mathrm{Al}_{1.79} \mathrm{Li}_{1.08} \mathrm{Mn}_{0.12} \mathrm{Fe}_{0.01}\right)$ $\mathrm{Al}_{6.0}\left(\mathrm{Si}_{5.91} \mathrm{Al}_{0.09}\right)\left(\mathrm{BO}_{3}\right)_{3} \mathrm{O}_{18}\left(\mathrm{OH}_{3}\right)\left(\mathrm{F}_{0.37} \mathrm{OH}_{0.37} \mathrm{O}_{0.27}\right)$, based on normalization to $15 \mathrm{Y}+\mathrm{Z}+\mathrm{T}$ with $\mathrm{Li}$ estimated by the Pesquera et al. (2016) approach, calculated B (to 3.0 apfu) and calculated $\mathrm{OH}$ (based on charge balance). Individual fibers display three distinct tourmaline generations showing effects of partial dissolution and reprecipitation, with each generation having distinct compositions (Fig. 3b): the earliest is foitite, followed by schorl, the elbaite/fluor-elbaite is the last generation fiber composition to form (Dutrow and Henry 2000, 2016). Calculated $\mathrm{Na}$ contents in the fluid coexisting with each tourmaline composition are, respectively, $0.23,0.43$ and $0.46 \mathrm{Na}_{\mathrm{fl}}$ mol/l (Fig. 3b). The compositional changes of tourmaline coupled with the dissolution-reprecipitation features of the fibers have been interpreted as a consequence of pocket ruptures allowing out-of-equilibrium fluid to infiltrate. This fluid partially dissolves pre-existing tourmaline and precipitates a new, stable composition of tourmaline as the pegmatite continues to fractionate (Fig. $3 b)$. The final tourmaline fiber chemistry is distinctly different from the host composition. Based on the textures and chemistry of the self-cannibalizing fibers and the host tourmaline, these different tourmaline morphologies likely record both the magmatic and hydrothermal processes occurring in the pegmatite. The host elbaite crystallized during pegmatite formation with fracturing and subsequent infiltration of compositionally distinct fluids that partially dissolved the host and reprecipitated the various generations of fibers during subsequent hydrothermal activity.

\subsection{Tourmaline as markers of shear/ detachment zones that channelized fluids}

Tourmalines, discovered at the South Summit of Mt. Everest, preserve evidence of fluid infiltration and $\mathrm{Na}$, B metasomatism associated with shear deformation (Corthouts et al. 2015). The Qomolangma Fm. limestones, forming the upper portion of Mt. Everest, record changes in strain and degree of metamorphism; from penetrative foliation and lower temperatures (calculated to be $\sim 250^{\circ} \mathrm{C}$ ) at the top to dynamic recrystallization and higher temperatures $\left(\sim 500^{\circ} \mathrm{C}\right)$ at the bottom (Corthouts et al. 2015). Small euhedral tourmalines occur near the base of the formation coexisting with phengitic muscovite, chlorite, biotite, alkali feldspar and calcite. Based on backscattered electron imaging and limited chemical analyses, tourmalines display minor zoning with an outer euhedral rim surrounding an inner zone that appears to have undergone dissolution prior to regrowth of tourmaline (see fig. 8 of Corthouts et al. 2015). Most of the tourmaline grains are dravite, a composition typical for metamorphosed limestones infiltrated by a B-bearing fluid (e.g. Henry and Dutrow 1996). Fluid composition calculations suggest that fluids contained $\mathrm{Na}_{\mathrm{fl}} \sim 0.38$ mol/l (see Dutrow and Henry 2016 for expressions). The absence of significant zoning and the localized occurrence of tourmaline is highly suggestive of crystallization from an Na, B-rich fluid that infiltrated the zone near the detachment. As such, these tourmalines represent not only a marker of fluid infiltration but are indicative of an area of enhanced permeability in the shear zone.

\section{Conclusions}

Tourmaline is a robust indicator of its host rock and fluid environment. Compositional variations on selected sites of the tourmaline supergroup-minerals and their textural variants provide a useful probe, both qualitatively and quantitatively, in deciphering the evolution of geothermal, hydrothermal and metamorphic environments. Although the fluids originally present with the crystallizing tourmaline have long escaped the system, tourmaline compositions provide insight into those dynamic fluids.

Acknowledgments. We are indebted to Milan Novák and Jan Cempírek for motivating, organizing, and enthusiastically supporting the Tourmaline 2017 conference. Their 
time and expertise brought together a worldwide group of tourmaline researchers for insightful and thoughtprovoking discussions furthering tourmaline research. We appreciate the community of tourmaline researchers for their stimulating advances and progress in elucidating this once obscure mineral. Thanks to Horst Marschall and Vincent van Hinsberg for highlighting yet-to-be-solved issues of the $\mathrm{O}-\mathrm{P}$ trend and which came first! We are grateful to the editors and to Vojtěch Janoušek for their patience and reviews and to Horst Marschall and Vincent van Hinsberg for thoughtful reviews that improved the manuscript.

\section{References}

Aranovich Ly Newton RC (1996) $\mathrm{H}_{2} \mathrm{O}$ activity in concentrated $\mathrm{NaCl}$ solutions at high pressures and temperatures measured by the brucite-periclase equilibrium. Contrib Mineral Petrol 125: 200-212

BaČ́́K P, KodĚra P, UHER P, Ozdín D, JÁNoŠíK M (2015) Chlorine-enriched tourmalines in hydrothermally altered diorite porphyry from the Biely Vrch porphyry gold deposit (Slovakia). Canad Mineral 53: 673-691

BaKsheev I, Prokef'ev VY, YaPaskurt VO, Vigasina MF, ZORINA LD, SOLOV'EV VN (2011) Ferric-iron-rich tourmaline from the Darasum gold deposit, Transbaikalia, Russia. Canad Mineral 49: 263-276

Berryman E, Wunder B, Wirth R, Rhede D, Schettler G, Franz G, HeInRICH W (2015) An experimental study on $\mathrm{K}$ and $\mathrm{Na}$ incorporation in dravitic tourmaline and insight into the origin of diamondiferous tourmaline from the Kokchetav Massif, Kazakhstan. Contrib Mineral Petrol 169: 1-16

Berryman E, Wunder B, Rhede D, Schettler G, Franz G, HeinRich W (2016) P-T-X controls on $\mathrm{Ca}$ and $\mathrm{Na}$ distribution between $\mathrm{Mg}-\mathrm{Al}$ tourmaline and fluid. Contrib Mineral Petrol 171: 31

Berryman E, Kutzschbach M, Trumbull R, Meixner A, Van Hinsberg V, Kasemann S, Franz G (2017) Tourmaline as a petrogenetic indicator in the Pfitsch Formation, Western Tauern Window, Eastern Alps. Lithos 283-284:138-155

BOUDREAUX AP (2014) Mineralogy and Geochemistry of the Erongo Granite and Interior Quartz-Tourmaline Orbicules and NYF-type Miarolitic Pegmatites, Namibia. Unpublished MSci. Thesis, University of New Orleans, New Orleans, pp 1-246

Cavarretta G, Puxeddu M (1990) Schorl-dravite-ferridravite tourmalines deposited by hydrothermal magmatic fluids during early evolution of the Larderello Geothermal Field, Italy. Econ Geol 85: 1236-1251

Cook RB (2013) Tourmaline: a giant of a "mineral". Rocks Mineral 88: 316-321
Corthouts TL, Lageson DR, Shaw CA (2015) Polyphase deformation, dynamic metamorphism, and metasomatism of Mount Everest's summit limestone, east central Himalaya, Nepal/Tibet. Lithosphere 8: 38-57

DieTRICH RV (1985) The Tourmaline Group. Van Nostrand Reinbold Co, New York, pp 1-300

Dingwell D, Pichavant M, Holtz F (1996) Experimental studies of boron in granitic melts. In: GREw ES, ANOviTZ LM (eds) Boron: Mineralogy, Petrology and Geochemistry. Mineralogical Society of America Reviews in Mineralogy 33: 331-385

Duchoslav M, Marks MaW, Drost K, McCammon C, Marschall HR, Wenzel T, Markl G (2017) Changes in tourmaline composition during magmatic and hydrothermal processes leading to tin-ore deposition: the Cornubian Batholith, SW England. Ore Geol Rev 83: 215-234.

Dutrow BL, Henry DJ (2000) Complexly zoned fibrous tourmaline, Cruzeiro mine, Minas Gerais, Brazil: a record of evolving magmatic and hydrothermal fluids. Canad Mineral 38: 131-143

Dutrow BL, Henry DJ (2016) Fibrous tourmaline: a sensitive probe of fluid compositions and petrologic environments. Canad Mineral 54: 311-335

Dutrow BL, Foster CT, Henry DJ (1999) Tourmaline-rich pseudomorphs in sillimanite zone metapelites: demarcation of an infiltration front. Amer Miner 84: 794-805

Etzel TM (2016) Oxygen Isotope Composition and Tourmaline Mineral Chemistry of the Coso and Darajat Geothermal Systems. Unpublished M Sci. Thesis, University of Utah, Salt Lake City, pp 1-139

Etzel TM, Moore JN, Bowman JR, Jones CG, Intani RG, Golla G, NaSh G (2015) Tourmaline in geothermal systems: an example from Darajat, Indonesia. GRC Trans 29: 529-536

Grice JD, ERCIT T (1993) Ordering of Fe and Mg in the tourmaline crystal structure - the correct formula. Neu Jb Mineral, Abh 165: 245-266

Griffin WL, Slack JF, Ramsden AR, Win TT, Ryan CG (1996) Trace elements in tourmalines from massive sulfide deposits and tourmalinites: geochemical controls and exploration applications. Econ Geol 91: 657-675

Hawthorne FC, Henry DJ (1999) Classification of the minerals of the tourmaline group. Eur J Mineral 11: 201-215

Hazarika P, Mishra B, Pruseth K (2015) Diverse tourmaline compositions from orogenic gold deposits in the Hutti-Maski Greenstone Blet, India: implications for sources of ore-forming fluids. Econ Geol 110: 337-353

HELGESON HC (1992) Effects of complex formation in flowing fluids on the hydrothermal solubilities of minerals as a function of fluid pressure and temperature in the critical and supercritical regions of the system $\mathrm{H}_{2} \mathrm{O}$. Geochim Cosmochim Acta 56: 3191-3207 
Henry DJ, Dutrow BL (1992) Tourmaline in a low grade clastic metasedimentary rock: an example of the petrogenetic potential of tourmaline. Contrib Mineral Petrol 112: 203-218

Henry DJ, Dutrow BL (1996) Metamorphic tourmaline and its petrologic applications. In: Grew ES, ANovitz LM (eds) Boron: Mineralogy, Petrology and Geochemistry. Mineralogical Society of America Reviews in Mineralogy 33: 503-557

HENRY DJ, DUTROw BL (2011) The incorporation of fluorine in tourmaline: internal crystallographic controls or external environmental influences? Canad Mineral 49: 41-56

Henry DJ, Dutrow BL (2012) Tourmaline at diagenetic to low-grade metamorphic conditions: its petrologic applicability. Lithos 154: 16-32

HenRY DJ, GUIDOTTI CV (1985) Tourmaline as a petrogenetic indicator mineral - an example from the staurolitegrade metapelites of NW Maine. Amer Miner 70: 1-15

HenRY DJ, KirKLAND BL, KiRKLAND DW (1999) Sectorzoned tourmaline from the cap rock of a salt dome. Eur J Mineral 11: 263-280

Henry DJ, Dutrow BL, Selverstone J (2004) Compositional asymmetry in replacement tourmaline - an example from the Tauern Window, Eastern Alps. Amer Miner 88: 1399-1399

Henry DJ, Sun H, Slack JF, Dutrow BL (2008) Tourmaline in meta-evaporites and highly magnesian rocks; perspectives from Namibian tourmalinites. Eur J Mineral 20: 889-904

Henry DJ, Novák M, Hawthorne FC, Ertl A, Dutrow BL, Uher P, Pezzotta F (2011) Nomenclature of the tourmaline-supergroup minerals. Amer Miner 96: 895-913

Jones C, Moore J, Bowman J, Walters M (2016) Higher temperature hydrothermal metamorphism at the Geysers Geothermal Field, California: an investigation of mineral chemistry and vein paragenesis from an active contact metamorphic environment. Proceedings of the $41^{\text {st }}$ Workshop on Geothermal Reservoir Engineering, Stanford Geothermal Program, SGP-TR-209. Stanford University, Stanford, CA, pp 1-18

KAWAKAMI T (2001) Tourmaline breakdown in the migmatites zone of the Ryoke metamorphic belt, SW, Japan. J Metamorph Geol 19: 61-75

Kister P, Vieillard P, Cuney M, Quirt D, Laverret E (2005) Thermodynamic constraints on the mineralogical and fluid composition evolution in a clastic sedimentary basin: the Athabasca Basin (Saskatchewan, Canada). Eur J Mineral 17: 325-341

LEEMAN W, Sisson J (1996) Geochemistry of boron and its implications for crustal and mantle processes. In: GrEW ES, Anovitz LM (eds) Boron: Mineralogy, Petrology and Geochemistry. Mineralogical Society of America Reviews in Mineralogy 33: pp 645-707
Lensing-Bergdorf M, Watenphul A, Schlüter J, MiHAILOVA B (2017) Crystal chemistry of tourmalines from the Erongo Mountains, Namibia, studied by Raman spectroscopy. Eur J Mineral 29: 1-11

London D, Morgan GB, Wolf MD (1996) Boron in granitic rocks and their contact aureoles. In: GREw ES, Anovitz LM (eds) Boron: Mineralogy, Petrology and Geochemistry. Mineralogical Society of America Reviews in Mineralogy 33: 299-330

Lussier AJ, HAWTHORNE FC (2011) Oscillatory zoned liddicoatite from Anjanabonoina, central Madagascar. II. Compositional variation and mechanisms of substitution. Canad Mineral 49: 89-104

LyNCh G, Ortega S (1997) Hydrothermal alteration and tourmaline-albite equilibria at the Coxheath porphyry $\mathrm{Cu}-\mathrm{Mo}-\mathrm{Au}$ deposit, Nova Scotia. Canad Mineral 35: 79-94

Marschall H, JiANG S-J (2011) Tourmaline isotopes: no element left behind. Elements 7: 313-319

MARSCHALl H, FörSTER G (eds) (2018) Boron Isotopes The Fifth Element. Springer, Berlin, pp 1-288 pp

Marschall HR, Korsakov AV, Luvizotto GL, Nasdala L, LuDwig T (2009) On the occurrence and boron isotopic composition of tourmaline in (ultra)high-pressure metamorphic rocks. J Geol Soc, London 166: 811-823

Moore JN, Christenson BW, Allis RG, Browne PRL, Lutz SJ (2004) The mineralogical consequences and behavior of descending acid-sulfate waters: an example from the Karaha-Telaga Bodas geothermal system, Indonesia. Canad Mineral 42: 1483-1499

Morgan GB IV, London D (1989) Experimental reactions of amphibole with boron-bearing fluids at $200 \mathrm{MPa}$ : implications for tourmaline stability and partial melting in mafic rocks. Contrib Mineral Petrol 102: 281-297

Morton A, Whitham AG, Fanning CM (2005) Provenance of Late Cretaceous to Paleocene submarine fan sandstones in the Norwegian Sea: integration of heavy mineral, mineral chemical and zircon age data. Sediment Geol 182: 3-28

NoRTON D (1978) Source-lines, source-regions, and pathlines for fluids in hydrothermal systems related to cooling plutons. Econ Geol 73: 21-28

Norton D, Dutrow BL (2001) Complex behavior of magma-hydrothermal processes: role of supercritical fluid. Geochim Cosmochim Acta 65: 4009-4017

Pesquera A, Torres-Ruiz J, Garcia-Casco A, Gil-Crespo PP (2013) Evaluating the controls on tourmaline formation in granitic systems: a case study on peraluminous granites from the Central Iberian Zone (CIZ), Western Spain. J Petrol 54: 609-634

Pesquera A, Gil-Crespo PP, Torres-Ruiz F, Torres-Ruiz J, RodA-Robles E (2016) A multiple regression method for estimating $\mathrm{Li}$ in tourmaline from electron microprobe analyses. Mineral Mag 80: 1129-1133 
Pezzotta F, Laurs BM (2011) Tourmaline: the kaleidoscopic gemstone. Elements 7: 333-338

SLACK J (1996) Tourmaline associations with hydrothermal ore deposits. In: Grew ES, ANovitz LM (eds) Boron: Mineralogy, Petrology and Geochemistry. Mineralogical Society of America Reviews in Mineralogy 33: pp 558-643

Slack JF, Trumbull RB (2011) Tourmaline as a recorder of ore-forming processes. Elements 7: 321-326

Trumbull RB, Krienitz MS, Gottesmann B, WieDENBECK M (2008) Chemical and boron-isotope variations in tourmalines from an S-type granite and its source rocks: the Erongo granite and tourmalinites in the Damara Belt, Namibia. Contrib Mineral Petrol 155: $1-18$

Trumbull RB, Slack JF, Krienitz MS, Belkin HE, WIEDENBECK M (2011) Fluid sources and metallogenesis in the Blackbird $\mathrm{Co}-\mathrm{Cu}-\mathrm{Au}-\mathrm{Bi}-\mathrm{Y}-\mathrm{REE}$ district, Idaho, U.S.A.: insights from major-element and boron isotopic compositions of tourmaline. Canad Mineral 49: $225-244$

VAn Hinsberg VJ (2011) Preliminary experimental data on trace-element partitioning between tourmaline and silicate melt. Canad Mineral 49: 153-163

VAN HINSBERG VJ, SCHUMACHER JC (2007) Intersector element partitioning in tourmaline: a potentially powerful single crystal thermometer. Contrib Mineral Petrol 153: 289-301

VAN Hinsberg VJ, Schumacher JC (2011) Tourmaline as a petrogenetic indicator mineral in the Haut-Allier metamorphic suite, Massif Central, France. Canad Mineral 49: $177-194$ van Hinsberg VJ, Henry DJ, Marschall HR (2011a) Tourmaline: an ideal indicator of its host environment. Canad Mineral 49: 1-16

van Hinsberg VJ, Henry DJ, Dutrow BL (2011b) Tourmaline as a petrologic forensic mineral: a unique recorder of its geologic past. Elements 7: 327-332

van Hinsberg VJ, Franz G, Wood BJ (2017) Determining subduction-zone fluid composition using a tourmaline mineral probe. Geochem Persp Let 3: 160-169

von Goerne G, Franz G (2000) Synthesis of Ca-tourmaline in the system $\mathrm{CaO}-\mathrm{MgO}-\mathrm{Al}_{2} \mathrm{O}_{3}-\mathrm{SiO}_{2}-\mathrm{B}_{2} \mathrm{O}_{3}-\mathrm{H}_{2} \mathrm{O}-\mathrm{HCl}$. Mineral Petrol 69: 161-182

von Goerne G, Franz G, Robert JL (1999) Upper thermal stability of tourmaline plus quartz in the system $\mathrm{MgO}$ $\mathrm{Al}_{2} \mathrm{O}_{3}-\mathrm{SiO}_{2}-\mathrm{B}_{2} \mathrm{O}_{3}-\mathrm{H}_{2} \mathrm{O}$ and $\mathrm{Na}_{2} \mathrm{O}-\mathrm{MgO}-\mathrm{Al}_{2} \mathrm{O}_{3}-\mathrm{SiO}_{2}-$ $\mathrm{B}_{2} \mathrm{O}_{3}-\mathrm{H}_{2} \mathrm{O}-\mathrm{HCl}$ in hydrothermal solutions and siliceous melts. Canad Mineral 37: 1025-1039

von Goerne G, Franz G, van Hinsberg VJ (2001) Synthesis of tourmaline solid solutions in the system $\mathrm{Na}_{2} \mathrm{O}-$ $\mathrm{MgO}-\mathrm{Al}_{2} \mathrm{O}_{3}-\mathrm{SiO}_{2}-\mathrm{B}_{2} \mathrm{O}_{3}-\mathrm{H}_{2} \mathrm{O}-\mathrm{HCl}$ and the distribution of $\mathrm{Na}$ between tourmaline and fluid at 300 to $700{ }^{\circ} \mathrm{C}$ and $200 \mathrm{MPa}$. Contrib Mineral Petrol 141: 160-173

von Goerne G, Franz G, van Hinsberg VJ (2011) Experimental determination of $\mathrm{Na}-\mathrm{Ca}$ distribution between tourmaline and fluid in the system $\mathrm{CaO}-\mathrm{Na}_{2} \mathrm{O}-\mathrm{MgO}$ $\mathrm{Al}_{2} \mathrm{O}_{3}-\mathrm{SiO}_{2}-\mathrm{B}_{2} \mathrm{O}_{3}-\mathrm{H}_{2} \mathrm{O}$. Canad Mineral 49: 137-152

ŽÁČEK V, PETROV A, HYRŠL J (1998) Chemistry and origin of povondraite-bearing rocks from Alto Chapare, Cochabamba, Bolivia. J Czech Geol Soc 43: 59-67

ŽÁčEK V, Petrov A, HYRŠL J, ONDruš P (2000) Tourmalines of povondraite - "oxy-dravite" series from Alto Chapare, Cochabamba, Bolivia. Geolines 10: 78-79 